\title{
Securitizing Migration in the European Union: Greece and the Evros Fence
}

\author{
loannis N. Grigoriadis (D) and Esra Dilek (iD
}

Department of Political Science and Public Administration, Bilkent University, Ankara, Turkey

\begin{abstract}
This article focuses on the securitization of migration in Greece through the case of the Evros anti-immigrant fence. The fence was constructed in 2012 with the aim to limit the flow of irregular migration from Turkey to Greece. This paper explores the reasons why the Greek government decided to build the fence and its political implications by focusing on the securitization of migration in Greece both through practices and through securitizing rhetoric. The paper argues that the construction of the Evros fence is closely associated with changing perceptions of threat and the framing of migrants as risky and threatening both at the national and the EU levels.
\end{abstract}

\section{Introduction}

Uprisings and state failure in the Middle East and North Africa and the subsequent flow of refugees and asylum seekers towards Europe have strengthened the connection between security and migration in the context of national and EU politics. Migration has been linked to security threats both through institution-building, with the formation of various agencies and expansion of the security sector and bureaucracies, and also through the discourse of political actors who have tended to frame the issue in terms of threat and security. These two trends reflect the two strands of securitization theory that is mainly concerned with the social construction of security threats and the measures taken to deal with them. The discursive approach to securitization has been based on the importance of 'speaking security' while the sociological approach has been based on the role of 'practising security' through security institutions and actors. In terms of migration and border control within the EU context, both speaking and practising security have been regarded as crucial in the process of securitizing migration.

This article explores the construction of the Evros fence within the framework of securitization theory and builds upon recent arguments on the need to consider the 'discursive approach' and the 'practices approach' to securitization as complementary rather than contradictory to each other. The main argument is that the fence was constructed despite EU opposition and despite its cost in a period of economic crisis for Greece as a symbolic move enabled by the securitization of migration and border control both at the EU and at the national levels. Focusing on the national level, the 
article evaluates the securitization of migration within the framework of the political discourse that prevailed for the decision to build the fence. National-level discourse by political actors reveals that the construction of the fence was linked to the wider EUlevel migration and border control practices, as well as to the national-level perception of migration as a security issue.

\section{Securitization theory, migration and border control}

Securitization theory has grown in parallel with theoretical discussions on the changing meaning of security since the end of the Cold War. Two main trends have been marked: the 'broadening' of security by moving beyond conventional militaristic understanding, and its 'deepening' by including actors and levels beyond the state in security analysis. ${ }^{1}$ Broadening of security has meant the inclusion of a variety of issues such as economic and environmental issues, human rights and migration in the security agenda. It has also meant moving from a preoccupation with 'hard security issues' to 'soft security issues'. Deepening, on the other hand, has meant moving down the state level to the individual level or up the state level to the international level. Security now is considered as a wider concept involving a variety of issues and actors both below and above the state level. The main rationale beyond the broadening and the deepening of security is that traditional focus on military threats to state security is now inadequate for understanding and explaining the great variety of security-related issues at various levels.

Securitization theory emerged within the constructivist strand of research as an approach based on the notion of the social construction of security. As a concept, it was first put forward by scholars that belong to what has come to be known as the Copenhagen School. ${ }^{2}$ Securitization, according to the Copenhagen School, is the discursive ${ }^{3}$ process through which an issue is constructed as a threat to a community and calls for the deployment of exceptional measures to deal with the threat. ${ }^{4}$ Securitization occurs when 'a securitizing actor uses a rhetoric of existential threat and thereby takes an issue out of what under those conditions is "normal politics"' ${ }^{5}$ Dealing with the designated existential threat requires emergency measures and justifying actions outside of what is considered to be 'normal politics' for a society. From this viewpoint, there is a need for an existential threat that legitimizes the breaking of a rule to deal with that threat.

The main feature of the Copenhagen School's securitization theory is that it relies on the 'speech act'. According to the theory, it is the articulation of a security threat that forms the security action in the first place. It is the 'utterance' of security itself, i.e., its discursive articulation that moves an issue in the realm of security and enables to treat it within emergency politics. Therefore, securitization is based on rhetorical action by a securitizing actor. However, the utterance itself is not sufficient for securitization to take place. The securitizing move should be accepted by the audience that it appeals to and find resonance within that audience. ${ }^{6}$ Acceptance by the audience then allows for exceptional measures by political actors that would be resisted in periods when securitization is not the case. Therefore, the gist of the Copenhagen School's understanding of securitization is that it enables the adoption of exceptional measures for dealing with an issue that is constructed as a 'threat' to security.

Another strand of securitization scholars argues for the importance of security practices and bureaucracies for securitization. What has come to be known as the Paris School in 
securitization studies focuses on the role of practices by security professionals and bureaucracies in securitization. ${ }^{7}$ The Paris School understands securitization as the 'capacity to control borders, to manage threats, to define endangered identities, and to delineate the spheres of orders' ${ }^{8}$ From this perspective, beyond speech acts and discourse, securitization is deeply embedded in the 'empirical referents' of policy, including policy tools and instruments.' Therefore, moving beyond the 'logic of exception', this strand of research is based on the 'logic of routine' where the routinized practices of bureaucracies and security professionals are the main drivers of the process of securitization. ${ }^{10}$ Indeed, the 'practices approach' to securitization rests on the correlation between speech acts by political actors, the mobilization against some groups (such as migrants) and the field of security professionals. ${ }^{11}$ From this viewpoint, the 'logic of routine' embedded in the practices approach to securitization is understood as part of process of the governmentality ${ }^{12}$ of unease, referring to the process of securitization as a political technology reproducing threat perceptions and insecurity against specific groups.

Both the 'speech act' approach and the 'practices' approach to securitization have provided thoughtful accounts for the securitization of migration within the EU context. Migration has been part of the broadening security agenda where human mobility and border control are increasingly framed within security concerns. According to Ceyhan and Tsoukala, the securitization of migration involves a symbolic process and rhetorical arguments that are articulated based on four axes: socioeconomic, securitarian, identitarian and political. ${ }^{13}$ The securitarian axis involves arguments on loss of control that associates security with borders, internal and external security. Migration is increasingly regarded as a threat to the economy and to political identity in Europe. ${ }^{14}$ The economic framing of the issue is closely related to the process of globalization that itself has fuelled regional responses to migration flows and especially to those of an irregular nature. From a political economy perspective, migration flows are closely related to the wider transformation of the global economy and the reallocation of labour-intensive production to third countries that themselves are mainly migrant-sending countries due to worsening economic conditions. This leads states or supranational organizations such as the EU to the adoption of increasingly tight approaches with the purpose of countering the increasing migration flows and framing the issue in terms of threat to economy and security. ${ }^{15}$

Migration has, therefore, become part of the broadening agenda of security, as population movements, especially those that are named as 'irregular', have been increasingly associated with security and threat perceptions. Within the EU context, the securitization of migration has gone hand in hand with the Europeanization process and increasing integration since the 1990s. The establishment of a borderless internal area through the Schengen Treaty was accompanied by increased security measures and cooperation among member state authorities. Harmonization of conditions of entry and coordination on surveillance of borders are part of these cooperation measures taken after the abolition of internal borders and the formation of a Schengen Information System (SIS), ${ }^{16}$ all closely associated with security and threat perceptions at the external borders. ${ }^{17}$

Therefore, the securitization of migration in the EU is closely tied to borders and, more specifically, to the control of external borders. We can distinguish two tendencies in terms of border control:

(a) border control with the aim of securing the internal space; 
(b) blurring distinction between the internal and the external through the externalization of threats and the extra-territorialization of mobility control.

The EU's internal security concerns have been closely tied to this 'external dimension' ${ }^{18}$ Within this conception, irregular migration has been increasingly tied to the need to control external borders so as to stop irregular migrants before entering the internal EU area.

Analysing the securitization of migration in the EU context requires that we consider both the national and the EU levels. Increasing EU-level cooperation on migration and asylum has brought together the effort for common practices and measures in this area. At the same time, cooperation on migration control has acquired intergovernmental character where member states sustain their prerogatives in decisions regarding migration policy and border control. Moreover, the non-existence of internal borders has meant that external borders are of importance not only for countries that have them, but for all member states of the EU. This has inevitably linked national-level discussions on borders and security to the EU level and has enabled legitimization of national-level security practices by referring to the EU. This paper adds to these discussions by focusing on the border fence that was built on the Greek-Turkish land border in 2012 by analysing it within the discussions on the securitization of borders and migration. Both the Copenhagen School and the Paris School's approach to securitization are informative in understanding the fence-building practice in the Greek case.

\section{The construction of the Greek Evros fence: securitization at the national level?}

Considering the above, the construction of the Evros fence on the land border between Greece and Turkey in 2012 could be regarded as an exceptional measure enabled by the social construction of migration as a security threat by political actors in Greece. Migration became a security issue in Greece during the 1990s, when, following the end of the Cold War, the number of incoming migrants from Eastern and Southeastern Europe, in particular Albania, increased significantly. During the 2000s, the securitization of migration lost pace through laws that opened the room for naturalization of long-term migrants. Nonetheless, since the late 2000s, migration has again become a top security priority, as unprecedented numbers of migrants sought to enter the European Union due to war and state collapse in the Middle East and North Africa. Greek opinion leaders have increasingly tied migration to a rhetoric of threat and security.

\section{Securitization of migration in Greece in the 1990s and 2000s}

The securitization of migration in Greece started during the 1990s, deriving both from the discursive construction of migrants as a threat and from securitizing practices. This included an institutional configuration where police and even the military emerged as key actors in Greek migration policy, the use of restrictive regulatory tools such as the narrow definition of refugees and asylum seekers, and the visual representation of migrants in the media. ${ }^{19}$ During the 1990s, migration was securitized in Greece in elite and mass media rhetoric, in state policies and in public opinion. ${ }^{20}$ A sizeable part of xenophobic political and mass media rhetoric linked the increase in migration levels to increasing crime rates and stressed the need 
to exclude migrants from Greek society. In term of state policies, a restrictive immigration law was adopted in 1991 (Law 1975/1991) that put emphasis on preventing the entry of undocumented immigrants and facilitated deportation. The 1991 Immigration Act recognized the Greek police as the competent authority in immigration and asylum issues, and this added to the securitization of migration by granting authority on immigration and asylum over the main national security apparatus. In fact, issues related to aliens have for decades been a competency area for the Department of Aliens that is part of the Directorate of State Security of the Greek Police. ${ }^{21}$ During the 1990s, Greece remained a main destination country for migrants from Albania and a country of preference for migrants from other Balkan, postSoviet, Middle Eastern and South Asian countries. Greek immigration policy during the 1990s was based on arrest-and-deport of mainly migrants of Albanian origin who were then regarded as threats to 'ethnic purity and authenticity of the nation'. ${ }^{22}$ At the same time, Greek mass attitudes during this period were marked by a preference for cultural homogeneity and a security perception of migrants connecting migrants to increasing levels of crime. ${ }^{23}$

The securitization of migration gained momentum in the 2000s, following Greece's membership of the Schengen system that established a borderless internal area in the EU. The establishment of the Schengen borderless internal area led to increasing concern with external border control and the blurring between internal and external security. This was accompanied by the externalization of migration and border control to third countries and increasing concern with management of external borders and the increasing number of border security professionals. EU Member States with external borders such as Greece, Italy and Spain undertook the burden of increasing border control. At the same time, in terms of the Greek state policy in the area of migration, the first half of the 2000s was marked by two laws, Law 2910/2001 titled 'Entry and Stay of Aliens in Greek Territory: Acquisition of Greek Citizenship by Naturalization and Other Provisions', ${ }^{24}$ and Law 3386/2005 later modified by law (3536/2007) 'On the Entry, Residence and Social Integration of Third Country Nationals on Greek Territory' .${ }^{25}$ These two laws were the result of EU directives to the Greek legal order and introduced restricted provisions for regularization of migrants in Greece of mainly Albanian origin, reiterating the restrictive management of migrants in Greece. ${ }^{26}$

Following the mid-2000s, Greece was transformed from a destination to a transit country for migrants coming from sub-Saharan and Middle Eastern countries ${ }^{27}$ who sought to enter other EU countries such as Germany. Since 2008, migration debates in Greece have reached crisis levels due to the economic plight, the increasing flow of migrants from the Middle East and North Africa, and the rise of extreme right-wing political parties especially since $2010 .^{28}$ The Syrian civil war has led to a sharp increase in migrants and asylum seekers who have fled war and crossed the sea and land borders of mainly Italy and Greece to get to other European countries. Furthermore, domestic political developments in Greece since 2010 have revealed the rise of anti-immigrant sentiment. The far-right Greek party Golden Dawn increased its votes from less than 0.3 per cent to 7.3 per cent in the May 2010 and to 6.9 per cent in the January 2015 general elections. The meteoric size of Golden Dawn support revealed the rise in feelings that the mass arrival of migrants is a threat to Hellenic identity and national security. ${ }^{29}$ 


\section{The Evros fence: exceptional security measure against migrants}

The Evros fence was constructed in 2012 on the Greek side of the land border between Greece and Turkey, between the village of Kastanies and the town of Nea Vyssa, at a length of $10.3 \mathrm{~km}$. The decision to construct the fence was revealed in late 2010 as a measure against the increasing number of irregular migrants entering Greece through the land border between Greece and Turkey. ${ }^{30}$ Construction of the fence started in May 2012 and was completed in December 2012 at a cost of US\$ 3.3 million. The construction of the fence was controversial ${ }^{31}$ on the grounds that it was erected amid the economic crisis that had plagued Greece since $2008 .^{32}$

In addition, the construction of the fence raised controversy with EU authorities. In January 2011, the European Commissioner for Home Affairs Cecilia Malmström had already announced that the EU did not accept that the fence be included in the 2011 External Border Funds programme. Malmström underlined that the Commission confirmed its 'readiness to finance other more effective measures within the comprehensive strategy that Greek authorities have planned to establish to ensure integrated border management' and that 'Greece remains free to decide to finance the construction of a technical barrier with national resources. ${ }^{33}$ In May 2011, the European Commission clearly declared its opposition to its construction stating that a fence would not solve the problem of irregular migration and stated that it would not provide funding for its construction, ${ }^{34}$ despite initial expectations from the Greek side. ${ }^{35}$ Following Greece's request in February 2012 to the European Commission for EU funds for construction of the fence, the European Commission spokesman Michele Cercone revealed in a press statement on 7 February 2012 that the European Commission had decided not to follow up the Greek request because it considered it pointless, as 'fences and walls are short term measures that do not solve the migration management issues in a structural way, ${ }^{36}$ Cercone underlined that Greece needed mediumand long-term reforms and structural measures to better manage its border in a modern and human way, and to address its migration and asylum challenges.

The decision to construct a fence also was taken in a period of acute economic, political and social crisis in Greece. The Greek sovereign debt crisis has been accompanied by a political crisis that led the country to several parliamentary elections and coalition governments. The construction of the fence amidst economic depression without EU funding was controversial; nonetheless, it helped the government divertif only temporarily-public attention from Greece's dire economic straits to a security issue. A survey conducted in 2011 revealed that while 46 per cent supported the project, 40 per cent of the respondents considered the cost for the construction of the fence unbearable under the circumstances of crisis. ${ }^{37}$ Legitimization of the fence was made through political rhetoric underlying the security aspect of the issue and the need to take strict and immediate measures on the borders. ${ }^{38}$

Despite these contradictions, the construction of the $10.3 \mathrm{~km}$ long fence was completed in August 2012. After construction of the Evros fence, the number of irregular migrants entering Greece through its land border with Turkey decreased significantly. ${ }^{39}$ However, this only meant that migrants searched for alternative routes, such as the sea borders in the southern Mediterranean, to enter Greece with the aim of moving to other EU countries. The construction of the fence could be regarded as a short-term measure for dealing with increasing irregular migration on the land border with Turkey. The 
fence was regarded as a drastic physical measure to stop the flow of irregular migrants on a daily basis through the land border. However, as the political discourse on the fence reveals, the construction of the fence entailed primarily symbolic value for disseminating the message that Greece is not an 'open gate' to Europe. Furthermore, its value was is reinforced by arguments on Greece fulfilling its duty to the EU as a 'gatekeeper' at the external borders and therefore protecting not only its citizens but the $\mathrm{EU}$ as a whole. Therefore, the construction of the fence was based on political rhetoric involving statements referring both to the national level and the EU level on the securitization of migration in Greece.

At the national level, discussions on the construction of the Evros fence date back to December 2010. ${ }^{40}$ Initial press statements on its construction by the Greek Police have underlined that the fence would not include electrified barbed wire because this is against international law but, rather, it would include thermal cameras and detection systems. ${ }^{41}$ This reveals the tendency to frame the construction of the fence as in accordance with already existing practices of screening and border control and indicating that the construction of the fence is not against the law, therefore it is legitimate. As part of the effort to increase the legitimacy of its construction, the Ministry of Social Order and Citizen Protection initiated an online consultation forum in August 2011 with the aim to provide information on the fence and gather citizens' views on its construction. ${ }^{42}$ The online consultation forum provided a detailed analysis of the project mainly in terms of its technical background and infrastructure and not the sociopolitical context that led to the decision to build it. The opening paragraph of the online description of the project briefly introduces the fence's construction as a project responding to the 'need to curb illegal migration and illicit trade across the land border between Greece and Turkey'.

Initial political discussions on the Evros fence took place in January 2011 as part of discussions on the formation of a new asylum bill for the establishment of an asylum service and a first reception bureau in accordance with common EU laws and procedures on asylum issues. At a presentation made in the Parliament, the Minister of Citizen Protection Christos Papoutsis underlined the security aspect of the issue of irregular migration and the need to control borders: ${ }^{43}$

Illegal migration is a big issue; it is an issue of national security and survival. The issue of guarding and controlling the borders is undeniably part of national sovereignty.... As long as we remain witness to this phenomenon that is regarded as the second greatest contemporary problem after climate change, we will deal with the issue with 'half-measures' (and therefore with no real results/solutions).... The construction of a fence is not an isolated measure, as some would like to present it. If this was an isolated measure, it would be ineffective. It is part of a set of measures that the Ministry of Citizen Protection has undertaken. It is part of a holistic programme that is supported by the European Commission for the period 2010-2013.... It is hypocrisy that some who criticize Greece for being unable to guard its borders in accordance with the Schengen Agreement, and threaten us for expulsion from the Schengen Agreement, are now criticizing because Greece wants the obvious, i.e., to strengthen the guarding of her borders.

In his speech, Papoutsis underlined that a fence and not a wall would be constructed on the Evros land border, presenting it as a technical means that was part of a larger set of technical measures taken against irregular migration such as border patrol through 
thermal cameras. Accompanied by other measures such as thermal cameras, the fence would give the time that border guards needed to act against irregular migration. From this viewpoint, the construction of the fence added to securitization by taking practical measures on the border. At the same time, the construction of the fence was a symbolic move, as, according to Papoutsis, the human smugglers would realize that this border is not a 'gate for easy entrance'. Therefore, the fence was crucial for disseminating the message that the land border of Greece was protected against irregular migrants.

After initial discussions, the first official presentation on the construction of the fence was made by the then Minister of Social Order and Citizen Protection Christos Papoutsis in July 2011. Papoutsis presented the construction of the fence as part of the Integrated Border Management Programme that Greece initiated in 2011 as part of the EU-level process for the formation of a European Border Surveillance System (EUROSUR) that was decided in 2008 and became operational in 2013. The construction of the fence was part of a series of measures including the supply of technical means (helicopters supplied with thermal cameras, mobile X-ray units and mobile thermal cameras) and the establishment of SIS II, all part of practical securitizing measures. Papoutsis's presentation revealed the then Greek government's effort to present irregular migration as an EU-level problem:

Thanks to our efforts, the European Commission, Frontex, and the European Asylum Support Office have now undertaken an important role for supporting our national efforts for combating irregular migration. In this way, we brought Europe to our external borders and we revealed the European aspect of the problem. ${ }^{44}$

In a later presentation by Papoutsis in 2012, it was underlined that Greece applied the Global Approach to Migration and Mobility (GAMM), the EU's overarching framework for migration and asylum policy since 2005. The objectives of this approach covered both better organizing legal migration and preventing and combating irregular migration. ${ }^{45}$ Papoutsis underlined that in an EU that wanted to protect its borders and guarantee societal peace and cohesion, it was Greece's obligation to follow this path of controlling borders and combating irregular migration. As was the case with all external borders in the EU, the border guards on Evros were tasked with preventing entry and ensuring the safety not only of the population there but of the greater space of the EU. ${ }^{46}$ Papoutsis declared that the establishment of a National Coordination Centre for Border Surveillance and Control was a national obligation towards the EU within the framework of EUROSUR regarding the internal security of the Union. ${ }^{47}$

The construction of the fence did not only aim at the practical reduction and combating of irregular migration on the Greek-Turkish border. It also had symbolic value for the EU, since, according to the Minister of Citizen Protection Papoutsis, it would disseminate the message that Greece is serious in its border management. In the words of Papoutsis:

Greece is loyal to her duties to protect the borders of the EU for the formation of a European society with its own cultural identity and the guarantee of social and economic cohesion. This is also an opportunity to disseminate the message that Greece is not an 'unfenced backyard', ${ }^{48}$ i.e., a free-for-all, open-range area where people can enter with no control. We will never allow Greece to become a transit country. ${ }^{49}$

Papoutsis underlined that the Greek government had the obligation to protect the legal residents of Greece and to protect the EU itself that was a union of 'norms of security, 
societal peace, cohesion, and solidarity.$^{50}$ Papoutsis's speech was replete with references to normative statements such as humanitarianism and hospitality:

We will fight for the cohesion of the Greek society, the rights of Greek citizens, and beyond all, the values of the Greek culture that include humanity, love for the humans, and hospitality.... The Greek society is hospitable ... however, the social and economic conditions of the country do not allow for consuming all our love for humanity and hospitality. ${ }^{51}$

Reference to humanitarian principles and hospitality revealed the need to legitimize the fence project by juxtaposing these normative aspects with the existing social and economic crisis conditions in the country. The construction of the fence was presented as a measure that needed to be taken despite its contradiction with such principles and despite official opposition that the EU itself had declared. The construction of the fence was also accompanied by a surveillance system through thermal cameras and increasing patrols of the land border, all securitizing practices according to the Paris School. ${ }^{52}$ Thermal cameras and the construction of the fence were not the only measures taken for the problem of irregular migration. Along with those measures and the adoption of an effective asylum policy, Greece was obliged to establish reception and detention centres for migrants, so that they were not allowed to wander freely and influence local life and the social and economic organization of the Greek society. It seems that this discourse on migrants was informed by the visibility of migrants in cities and their involvement with local criminal networks. The establishment of such centres for those migrants who managed to get through external borders revealed the intention to control and confine migrants after they get into the EU space. This could be regarded as a complementary measure to the 'sealing' of external borders through measures such as the construction of a fence and increasing surveillance through cameras and border patrols. This revealed the blurring distinction between internal and external security concerns at the national level.

The construction of the fence and the application of the holistic programme for migration and border control at the national level required the hiring of security personnel. In his presentation, Papoutsis referred to the call by the EU for downsizing of the number of civil servants and personnel in the public sector in Greece as part of measures that Greece should take to solve the economic crisis and to discharge its financial debt. According to Papoutsis, security personnel should be exempt from downsizing as they were required to respond to the need for border control and protection. This revealed the increasing securitization through certain practices while it also came close to the arguments on a state of exception in the Copenhagen School's securitization theory and the need to consider the two strands as complementary to each other. Papoutsis presented the situation as exceptional and in need of extraordinary measures, that is, the employment of more security personnel instead of downsizing despite the economic crisis and despite the EU's call to do so. From a wider stance, the construction of the fence could be considered within the framework of the politics of exception by the then Greek government.

The argument on exceptionalism was broadened to include references to not only physical security and the visibility of migrants but also to health security. In a press release in April 2012, Minister of Citizen Protection Michael Chrysochoidis and the Minister of Health Andreas Loverdos stated that the migration issue was 'a health bomb ready for explosion that should be dealt with seriously and responsibly, against any kind of populism'. ${ }^{53}$ They stated that contagious diseases and crime rates were on the rise due to 
the increasing number of migrants. Furthermore, migrants were obliged to hold health identification as a prerequisite for their employment. Measures regarding health also included mobile patrols by the Centre of Control and Prevention of Diseases that would be able to stop migrants on the road for health checks. Furthermore, the living areas of migrants should fulfil health standards and there would be limitations in their use. These measures added to the rhetoric of existential threat as migrants were depicted as main threats to public health and the well-being of Greek society.

The Evros fence was not the only exceptional measure to be taken at the national level in this period. During the construction of the Evros fence in 2012, the Greek government initiated two national-level operations with the aim of combating irregular migration. 'Operation Aspida' (Shield) started in August 2012 with the deployment of 1800 border guards on the Evros border. ${ }^{54}$ Its main aim was to strengthen border controls through the increasing presence of Greek security forces on the border. ${ }^{55}$ The new Minister of Citizen Protection Nikos Dendias announced 'Operation Aspida' to the public by reporting to Greek news agencies that a body of 1800 border guards have been deployed to the Evros border to 'seal' the border against an expected influx of migrants especially from Syria due to political developments in that country. ${ }^{56}$ At the same time, another operation aiming at the reduction of irregular migrants within the country was initiated. The Operation 'Xenios Zeus' was launched in August 2012, ironically named after Zeus in his capacity as the ancient Greek god of hospitality. ${ }^{57}$ It was composed of regular operations in areas with a high migrant concentration that took place in both public places and in private areas, i.e., the houses where migrants stayed. ${ }^{58}$ Both operations pointed to securitizing practices not only on the borders and their control but also in cities where the visibility of migrants is increased.

These two operations were initiated at a time following political turmoil in Greece and the change of government after the June 2012 elections. The incumbent Minister of Public Order and Citizen Protection Nikos Dendias noted in a press release in 2012 that the new Greek government would not allow the country to become a 'migrant ghetto ${ }^{\text {,5 }}$ and therefore measures were taken to control borders and detain and deport immigrants living in cities. Dendias has also described the problem of immigrants as 'perhaps even bigger than our financial one, ${ }^{60}$ by revealing how migration was constructed as a security problem prioritized over all other issues, thus acquiring an exceptional character. In the words of Dendias:

The country is on the verge of extinction. It is the first time since the Dorian invasion 4000 years ago that the country has received such an invasion ... It is a bomb at the social and state bases.... Solving the migration problem requires nationwide engagement. We are on the verge of destruction. If we do not establish a holistic network for the management of migration we will collapse.... Migration is an even greater problem than the economic crisis. ${ }^{61}$

This rhetoric on exceptionalism has been the main driver at the national level of securitization of migration before and after the construction of the fence. Through this securitizing rhetoric, the construction of the fence was presented as a legitimate measure that Greece had to take both as a security measure at the national level and as a measure for the protection of the wider EU area. The symbolic message was restated by Dendias in a statement on 9 November 2012, shortly before the completion of the construction of the fence:

The construction of the fence is a measure, a highly symbolic choice that disseminates a message to the citizens of third countries who seek to make our country a transit to other 
EU countries. Control and security on our border with the neighbouring country [Turkey] will be strengthened. ${ }^{62}$

These statements by Greek political actors that acted as decision-makers in the construction of the Evros fence and the implementation of other measures related to the common approach to migration and border control reveal the interconnectedness of the EU and national-level discourses and practices of securitization. The EU-level surveillance and data-exchange practices that added to the securitization process were transferred to the national level as part of increasing integration in the field of migration policy. ${ }^{63}$ This meant that securitization through certain practices was reproduced at the national level as a result of increasing integration. For its part, securitization through various practices also fed the discourse and 'speech acts' of securitization at the national level. Exceptional measures were legitimized with reference to the need for security at both the national level and the EU level. Within this conception, irregular migration had to be stopped at the external borders with the aim of protecting both the Greek citizens and their national identity and the EU area at large. This was presented as a responsibility that member states should undertake as part of their obligation as member states of the EU.

\section{Conclusion}

The construction of the Evros anti-immigrant fence on the Greek-Turkish land border has been closely related to the securitization of migration both at the EU and at the national level. Migration has been increasingly securitized at the EU level since the early 2000s, after the establishment of the Schengen borderless internal area and increasing concern regarding management of external borders. Migration was also securitized in Greece through national-level policies and the framing of migrants as a security issue, especially since the last decade with an increasing flow of immigrants from North African, Middle Eastern and South Asian countries. As part of increasing integration and cooperation in migration policy and border control, institutional practices at EU level were also transferred to the national level in Greece.

In Greece, the decision to construct a fence on the Greek-Turkish border in 2011 was part of both Greece's national politics and the increasing integration regarding migration policy at the EU level. The decision to construct a fence is at the intersection of Greece's national interests and its 'duties', in the words of the political actors that decided its construction, towards the EU. It is both the result of the discursive construction of migration and migrants as a security issue and the practical measures taken. Indeed, it may be argued that EU-level securitization and transfer of security practices enabled the discursive legitimization of the construction of the fence.

Beyond interconnectedness at the EU level, the construction of the fence was legitimized at the national level on the grounds of its symbolic power. Political rhetoric in Greece before and during construction of the fence has been based on the importance of the fence as a security measure that will both physically and symbolically stop irregular migration and add to the fight against it. The fence was constructed as part of the effort to disseminate the message that Greece was not an open entry-point for irregular migrants. At the same time, the fence provided a symbolic message that 
Greece was successful in undertaking its responsibility to protect its borders both as a sovereign country and as an EU member state.

Our analysis reveals that, in the EU context, securitization theory should be considered in an interactive way in two manners: first, between the EU and the national level, and second, between the two strands of securitization theory, the practices approach and the speech-act approach. Discourses and practices are in an interactive relationship, as securitizing practices at the borders such as surveillance and the increase in security personnel go hand in hand with securitizing rhetoric by political actors. The case of the Evros fence reveals this interactive relationship where the national-level rhetoric on the construction of the fence was accompanied by security practices on the ground. At the same time, examination of the national level discourse regarding the Evros fence reveals that institutional decisions and practices at the EU level provided a ground for legitimizing the construction of the fence despite the absence of EU support and despite Greece's economic hardship.

\section{Notes}

1. K. Krause and C. M. Williams, Broadening the Agenda of Security Studies: Politics and Methods, Mershon International Studies Review, 40 (2), Oct. 1996, p. 230.

2. The distinction between different 'schools' of securitization research such as the Copenhagen School and the Paris School is regarded with criticism by some scholars, as such distinctions simplify actual theoretical constellations. See for example T. Balzacq, S. Leonard and J. Ruzicka, "Securitization" revisited: theory and cases', International Relations, 30 (4), 2015, pp. 5-6.

3. We use the term 'discursive' to refer to the Copenhagen School's approach to securitization as the social construction of security threats through their discursive articulation. On this, see B. Buzan and O. Waever, Regions and Power: The Structure of International Security, Cambridge, Cambridge University Press, 2003.

4. Ibid., p. 491.

5. B. Buzan, O. Waever and J. de Wilde, Security: A New Framework for Analysis, London, Lynne Rienner, 1998, p. 24.

6. Ibid., p. 25. The Copenhagen School's reliance on the speech act has been criticized on various grounds. One main criticism is that this approach is based on an internalist view', viewing language (the 'utterance') itself as being the main engine for securitization. This disregards the existence of external threats that do not depend on language and are part of the securitization process. On this, see T. Balzacq, 'The three faces of securitization: political agency, audience and context', European Journal of International Relations, 11(2), 2005, pp. 171-201. Also, the internalist view treats speech acts as too static and does not consider their 'embeddedness' in the social context in which it takes place. On this see, H. Stritzel, 'Towards a theory of securitization: Copenhagen and beyond', European Journal of International Relations, 13(3), 2007, pp. 357-383. Reliance on language is problematic on two more grounds. On this, see M. McDonald, 'Securitization and the construction of security', European Journal of International Relations, 14(4), 2008, p. 568. First, on the grounds that language is not the only means through which securitization is being communicated. One main argument is that images should be regarded as powerful in the process of securitization as speech. On this see, L. Hansen, 'The politics of securitization and the Muhammad cartoon crisis: a post-structuralist perspective', Security Dialogue, 42(4-5), 2011, pp. 357-369. Second, focusing on language excludes bureaucratic practices and physical action that themselves add to the process of securitization. On this, see D. Bigo, 'Security and 
immigration: towards the governmentality of unease', Alternatives: Global, Local, Political, (27), 2002, pp. 63-92.

7. Bigo, 'Security and immigration', op. cit.; D. Bigo, 'The (in)securitization practices of the three universes of EU border control: military/navy-border guards/police- database analysts', Security Dialogue, 45(3), 2014, pp. 209-225.

8. CASE Collective, 'Critical approaches to security in Europe: a networked manifesto', Security Dialogue, 37(4), 2006, p. 457.

9. T. Balzacq, 'The policy tools of securitization: information exchange, EU foreign and interior policies', JCMS: Journal of Common Market Studies, 46(1), 2008, pp. 75-100.

10. P. Bourbeau, 'Moving forward together: logics of the securitization process', MillenniumJournal of International Studies, 43(1), 2014, pp. 187-206.

11. Bigo, 'Security and immigration', op. cit., p. 65.

12. The notion of governmentality is adopted from Michel Foucault's work. On this, see ibid., p. 86, J. Huysmans, The Politics of Insecurity: Fear, Migration, and Asylum in the EU, London and New York, Routledge, 2006, pp. 97-98.

13. A. Ceyhan and A. Tsoukala, 'The securitization of migration in western societies: ambivalent discourses and policies', Alternatives: Global, Local, Political, 27(1), 2002, pp. 23-24.

14. J. Huysmans, 'Contested community: migration and the question of the political in the EU', in Morten Kelstrup and Michael C. Williams (eds), International Relations Theory and the Politics of European Integration: Power, Security and Community, London, Routledge, 2000, pp. 149-170.

15. On this, see L. S. Talani, 'International migration: IPE perspectives and the impact of globalization', in Leila Simona Talani and Simon McMahon (eds), Handbook of the International Political Economy of Migration, Cheltenham and Northampton, MA, Edward Elgar Publishing, 2015, pp. 29-32.

16. The SIS is a large-scale information system that was established in 1990 that supports external border control and law enforcement cooperation among EU member states. It enables competent authorities such as police and border guards to undertake coordination activities (for detailed information see European Commission DG Migration and Home Affairs, Schengen Information System-What Is the Schengen Information System, European Commission, Brussels, 2015), available from http://ec.europa.eu/dgs/homeaffairs/what-we-do/policies/borders-and-visas/schengen-information-system/index_en. htm. A new generation-the SIS II-became active in 2013 with new functionalities such as enhanced alerts on persons and objects, direct queries and a central system, and the use of biometric data (fingerprints and photograph) (detailed information available at European Commission, Memo: Questions and Answers: Schengen Information System (SIS II), European Commission: Brussels, 2013), available from http://europa.eu/rapid/ press-release_MEMO-13-309_en.htm .

17. A. Faure Atger, 'The abolition of internal border checks in an enlarged Schengen Area: freedom of movement or a web of scattered security checks?', Challenge: Liberty and Security Research Paper No. 8, 2008, p. 6.https://www.files.ethz.ch/isn/54548/CP008\% 20The\%20Abolition\%20of\%20Internal\%20Border\%20Checks.pdf

18. W. Rees, 'Inside out: the external face of EU internal security policy', Journal of European Integration, 30(1), 2008, pp. 97-111.

19. G. Karyotis, 'Securitization of migration in Greece: process, motives, and implications', International Political Sociology, 6(4), 2012, pp. 390-408.

20. J. Swarts and N. M. Karakatsanis, 'Challenges to desecuritizing migration in Greece', Journal of Balkan and Near Eastern Studies, 15(1), 2013, pp. 33-51.

21. G. Mavrodi, "The other side of "Fortress Europe": policy transfers in the EU and the liberalizing effects of EU membership on Greek immigrant policy,' in Center on Migration, Citizenship and Development (COMCAD) Working Paper (2010), p. 9. Informed by the sociological view of securitization based on the practices of security professionals, a recent study on security professionals in Greece reveals how migration is linked to criminality, fear of economy, and fear of cultural and demographic erosion. G. Lazaridis and D. 
Skleparis, 'Securitization of migration and the neo-Nazi: the case of Greek security professionals', International Migration, 54(2), 2016, pp. 176-192.

22. A. Triandafyllidou, 'Greek immigration policy at the turn of the 21 st century. lack of political will or purposeful mismanagement?', European Journal of Migration and Law, 11 (2), 2009, p. 162.

23. J. Swarts and N. M. Karakatsanis, 'The securitization of migration: Greece in the 1990s', Journal of Balkan and Near Eastern Studies, 14(1), 2012, pp. 33-51.

24. Hellenic Republic, Law 2910/2001: Entry and Stay of Aliens in Greek Territory. Acquisition of Greek Citizenship by Naturalisation and Other Provisions, National Printing House, Athens, 2001, available from http://www.refworld.org/pdfid/3b209fd54.pdf (last accessed 13 July 2016).

25. Hellenic Republic, Law 3386/2005: Codification of Legislation on the Entry, Residence and Social Integration of Third-Country Nationals on Greek Territory, National Printing House, Athens, 2005, available from http://www.mfa.gr/switzerland/images/docs/ethnikes_theori seis/codification_of_legislation_en.pdf (last accessed 13 July 2016).

26. Triandafyllidou, op. cit., p. 173.

27. I. Papageorgiou, 'The Europeanization of immigration and Asylum in Greece (1990-2012)', International Journal of Sociology, 43(3), 2013, pp. 72-90.

28. A. Triandafyllidou and M. Ambrosini, 'Irregular immigration control in Italy and Greece: strong fencing and weak gate-keeping serving the labour market', European Journal of Migration and Law, 13(3), 2011, p. 262.

29. See N. Nielsen, 'Fortress Europe: a Greek wall close up', EUobserver, 21 December 2012 (last accessed 24 May 2016).https://euobserver.com/fortress-eu/118565

30. According to the Frontex Annual Risk Analysis (ARA) in 2010, Greece accounted for the 75 per cent of all detections of illegal border crossings in the EU in 2010 Frontex, Frontex Annual Risk Analysis, European Agency for the Management of Operational Cooperation at the External Borders of the Member States of the European Union, 2010, p. 3.

31. See D. Leivada, 'Why Greece shut the shortest, safest route for migrants and refugees', Huffington Post, 14 October 2015 (last accessed 25 May 2016).https://www.huffingtonpost. com/entry/greeceturkey-border-fence_us_55f9ab73e4b0d6492d63ec12

32. For a brief summary on the Greek financial crisis see L. Alderman et al., 'Explaining Greece's debt crisis', New York Times, 17 June 2016 (last accessed 24 May 2016). https:// www.nytimes.com/interactive/2016/business/international/greecedebt-crisis-euro.html

33. European Parliament, Parliamentary Questions: Answer Given by Ms Malmström on Behalf of the Commission, European Parliament, Strasbourg, 2012, available from http://www. europarl.europa.eu/sides/getAllAnswers.do? reference=E-2012-000105\&language $=$ en [posted on 24/2/2012] (last accessed 13 July 2016).

34. On this, see E-Kathimerini News Desk, 'EU will not fund Evros fence', Kathimerini English Edition, 6 December 2011 (last accessed 25 May 2016).http://www.ekathimerini.com/ 137519/article/ekathimerini/news/eu-will-not-fund-evros-fence

35. Response by the Minister of Citizen Protection in Parliament, on 4 August 2011. Available at Hellenic Parliament, Response by Minister of Citizen Protection Christos Papoutsis to Questions of Two Members of Parliament on 'Construction of an Artificial Obstacle (Fence) on River Evros', Athens, 2011, available from http://www.hellenicparliament.gr/UserFiles/ 67715b2c-ec81-4f0c-ad6a-476a34d732bd/7459324.pdf [posted on 4/8/2011] (last accessed 24 May 2016).

36. EUbusiness News Desk, EU Refuses to Fund 'Pointless' Greece-Turkey Border Fence, EUbusiness, Brussels, 2012, available from http://www.eubusiness.com/news-eu/greeceimmigration.f17/ [posted on 7 February 2011] (last accessed 13 July 2016).

37. Available at Public Issue, 'Public opinion against the "wall” of Evros [H Kotví $\Gamma \nu \omega \dot{\mu \eta}$

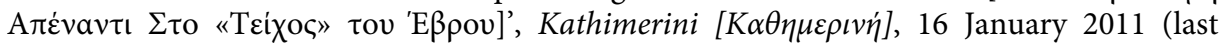
accessed 29 July 2016). https://www.publicissue.gr/1619/wall-survey-2011/

38. A. Triandafyllidou, 'Greek migration policy in the 2010s: Europeanization tensions at a time of crisis', Journal of European Integration, 36(4), 2014, p. 27. 
39. According to border guards, the construction of the fence led to a drop of 95 per cent in irregular migrant arrivals through the land border. However, this was accompanied by an increase of 231 per cent in arrests of irregular migrants at sea borders D. Aggeli, A. Dimitriadi and A. Triandafyllidou, Assessing the Cost-Effectiveness Relationship of the

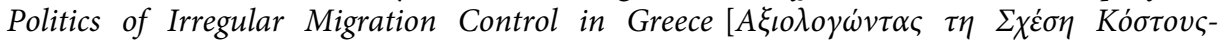

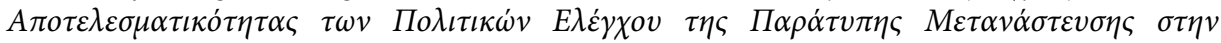
$E \lambda \lambda \alpha \dot{\alpha} \delta \alpha$ ], Athens: ELIAMEP, October 2014, p. 34. http://www.eliamep.gr/wp-content/ uploads/2014/11/MIDAS-REPORTGR-1.pdf

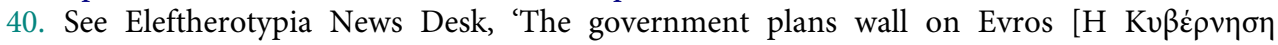

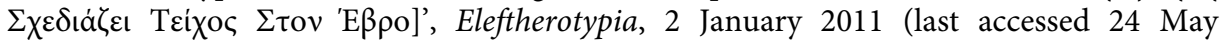
2016). http://www.enet.gr/?i=news.el.article\&id=237517

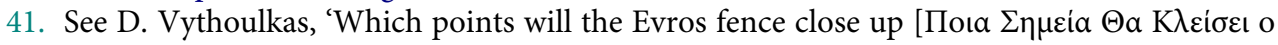

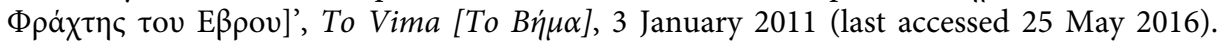
http://www.tovima.gr/society/article/?aid=376007

42. Detailed description of the fence construction project is available at Hellenic Republic,

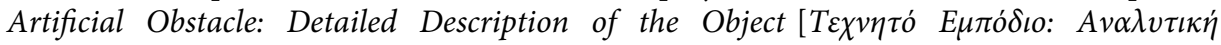

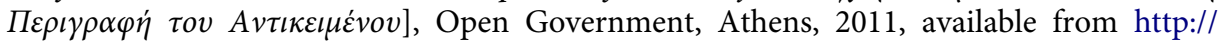
www.opengov.gr/yptp/?p=539 [posted on 20 August 2011] (last accessed 25 May 2016).

43. Available at Hellenic Ministry of Citizen Protection, 'News bulletin on the talk of Minister of Citizen Protection Christos Papoutsis at the Parliament during the discussion

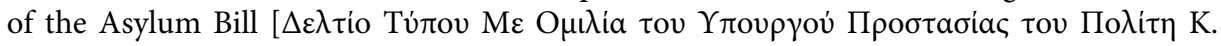

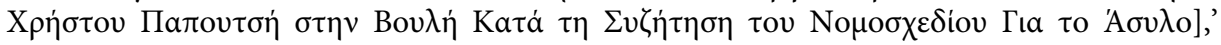
Athens, 2011 (last accessed 13 June 2016). http://www.minocp.gov.gr/index.php?option= ozo_content\&lang=\&perform $=$ view\&id=3411\&Itemid $=461$

44. See Hellenic Ministry of Citizen Protection, Presentation by Minister of Citizen Protection Christos Papoutsis at the Cabinet (6/9) on the Holistic Program of Border Management and

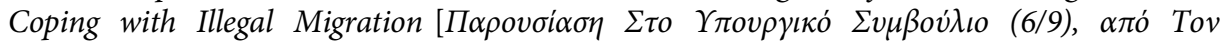

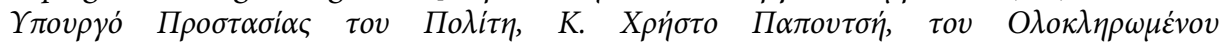

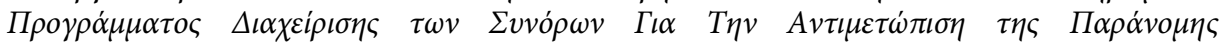

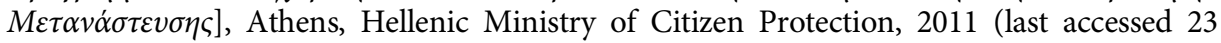
May 2016). http://www.hellenicparliament.gr/UserFiles/67715b2c-ec81-4f0c-ad6a476a34d732bd/7492580.pdf

45. European Commission DG Migration and Home Affairs, Global Approach to Migration and Mobility, European Commission, Brussels, 2016, available from http://ec.europa.eu/ dgs/home-affairs/what-we-do/policies/international-affairs/global-approach-to-migration/ index_en.htm (last accessed 24 May 2016).

46. P. Pallister-Wilkins, 'The humanitarian politics of European border policing: Frontex and border police in Evros', International Political Sociology, 9(1), 2015, pp. 53-69.

47. Hellenic Coast Guard, Presentation of the Study of the Security Studies Centre of the

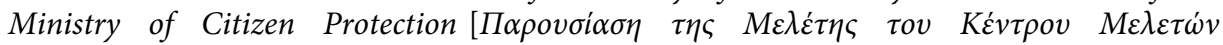

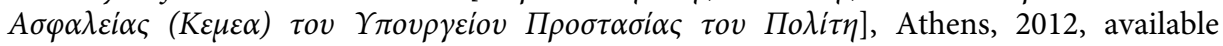
from http://www.hcg.gr/node/2026 (last accessed 25 May 2016).

48. In the words of Christos Papoutsis: 'The message, therefore, is clear, simple and explicit: Greece is no unfenced vineyard [ $\left.\xi \dot{\varepsilon} \varphi \rho \alpha \gamma_{0} \alpha \mu \pi \dot{\varepsilon} \lambda_{\mathrm{l}}\right]$.' 'Unfenced vineyard' is a Greek proverbial expression for unprotected property, prone to looting and incursions.

49. Hellenic Ministry of Citizen Protection, 'News Bulletin on the Inauguration of Operational Centre for Border Control and the Launch of Construction Works of a Deterrent Artificial Obstacle by the Minister and the Deputy Minister of Citizen Protection $[\Delta \varepsilon \lambda \tau i$ Túrov $\Gamma\llcorner\alpha \tau a$

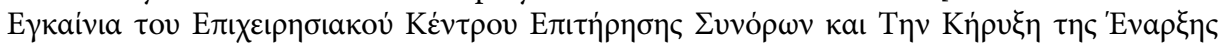

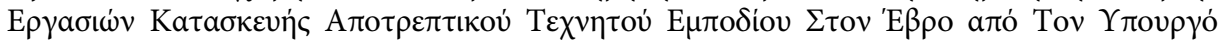

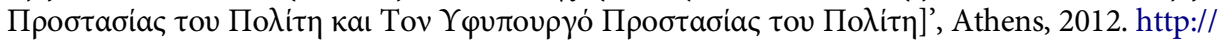
www.minocp.gov.gr/index.php?option $=$ ozo_content\&lang $=\&$ perform $=$ view \&id $=$ 4076\&Itemid $=529 \hat{A}$ 
50. See Kathimerini News Desk, 'Wall at Evros for deterringthe the entry of aliens' [Téxos

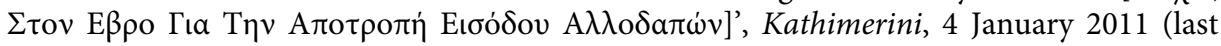
accessed 24 May 2016). http://www.kathimerini.gr/414757/article/epikairothta/politikh/ teixos-ston-evro-gia-thn-apotroph-eisodoy-allodapwn

51. Hellenic Ministry of Citizen Protection, op. cit.

52. Bigo, 'Security and Immigration', op. cit.

53. Available at Ethnos News Desk, 'Health controls to all immigrants-press conference by

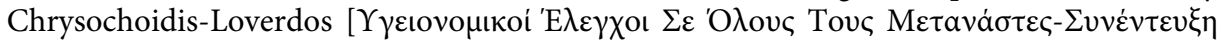

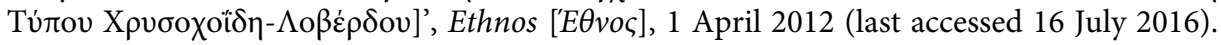
http://www.ethnos.gr/koinonia/arthro/ygeionomikoi_elegxoi_se_olous_tous_metanastes63638394/

54. See Ethnos News Desk, “'Shield' against illegal migration on Evros is effective

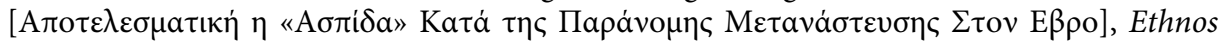

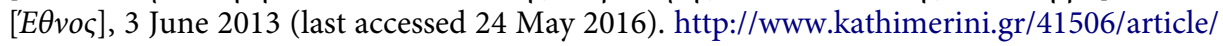
epikairothta/ellada/apotelesmatikh-h-aspida-kata-ths-paranomhs-metanasteyshs-ston-evro

55. Hellenic Parliament, Response by Minister of Citizen Protection Nikos Dendias to Questions of Four Members of Parliament on 'Transfer of Border Guards to Reinforce Hellenic Police Services in Evros-Relevant Issues' Athens, 2012, available from http://www.hellenicparlia ment.gr/UserFiles/67715b2c-ec81-4f0c-ad6a-476a34d732bd/7696899.pdf [posted on 23 August 2012] (last accessed 26 May 2016).

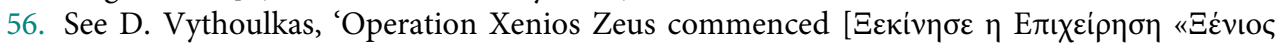

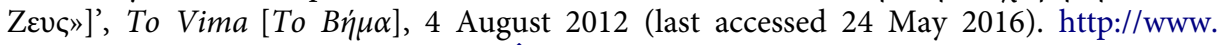
tovima.gr/society/article/?aid=469724ÂA

57. Operation 'Xenios Zeus' has been criticized for ethnic profiling of immigrants and arbitrary deprivation of liberty of those arrested, since fewer than 6 per cent of those arrested were not able to verify lawful stay in the country. On this, see E. Cossé, 'Xenios Zeus and the true meaning of Greek hospitality', OpenDemocracy, 9 July 2013 (last accessed 23 May 2016). https://www.hrw.org/news/2013/07/09/xenios-zeus-and-true-mean ing-greek-hospitality

58. Aggeli, Dimitriadi and Triandafyllidou, op. cit., p. 32.

59. See H. Smith, 'Greek crackdown on illegal immigrants leads to mass arrests', Guardian, 7 August 2012. https://www.theguardian.com/world/2012/aug/07/greece-crackdown-illegalimmigrants-arrest $\hat{A}$

60. Ibid. (last accessed 24 May 2016).

61. To Vima News Desk, 'N. Dendias on the migration issue: we face a new "invasion of the

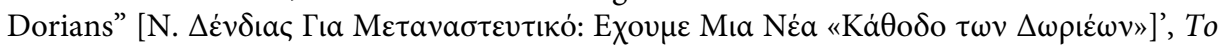
Vima [To Bí $\mu \alpha$ ], 6 August 2012. http://www.tovima.gr/society/article/?aid=469853

62. Hellenic Parliament, Response by Minister of Citizen Protection Nikos Dendias to Question of One Member of Parliament on 'Progress of Construction Works of an Artificial Obstacle (Fence) on River Evros Et Al.' Athens, 2012, available from http://www.hellenicparliament. gr/UserFiles/67715b2c-ec81-4f0c-ad6a-476a34d732bd/7814095.pdf [posted on 9 November 2012].

63. Bigo, 'The (in)securitization practices of the three universes of EU border control', op. cit.

\section{Disclosure statement}

No potential conflict of interest was reported by the authors.

\section{Notes on contributors}

Ioannis N. Grigoriadis is Associate Professor and Jean Monnet Chair of European Studies at the Department of Political Science and Public Administration, Bilkent University. His research 
interests include European, Turkish politics, nationalism and democratization. His recent publications include Instilling Religion in Greek and Turkish Nationalism: A 'Sacred Synthesis' (London and New York: Palgrave Macmillan, 2012), Trials of Europeanization: Turkish Political Culture and the European Union (London and New York: Palgrave Macmillan, 2009), 'The People's Democratic Party (HDP) and the 2015 elections', Turkish Studies, No. 1, March 2016, pp. 39-46.

Esra Dilek is a PhD Candidate at the Department of Political Science \& Public Administration, Bilkent University. Her research interests include migration, securitization, the Kurdish issue and conflict resolution.

\section{ORCID}

Ioannis N. Grigoriadis (D) http://orcid.org/0000-0003-0882-6125

Esra Dilek (D) http://orcid.org/0000-0002-6157-0504 